\title{
IDENTIFIKASI PENGARUH MJO FASE 3 TERHADAP CURAH HUJAN DI PULAU SUMATERA DAN JAWA (STUDI KASUS 14 - 17 OKTOBER 2018)
}

\author{
Rahpeni Fajarianti ${ }^{1}$, Deffi Munadiyat Putri ${ }^{2}$, Paulus Agus Winarso ${ }^{3}$ \\ ${ }^{1,2}$ Program Studi Meteorologi, Sekolah Tinggi Meteorologi Klimatologi dan Geofisika, \\ Jalan Perhubungan 1 No.5 Pondok betung, Pondok Aren, Tangerang Selatan \\ 3Sekolah Tinggi Meteorologi Klimatologi dan Geofisika \\ Email : rahpenifajarianti@gmail.com
}

\begin{abstract}
Madden Julian Oscillation (MJO) is a wave in tropical atmosphere that moving eastward from Indian ocean to Pacific Ocean for a period 30 - 60 days. There are many research that explain when MJO is active in phases 2, 3 and 4 it affects convective activities in the Indonesian Maritime Continent. The purpose of this study is to determine the effect of MJO in phase 3 on temporal rainfall intensity in Sumatra and Java island on 14 - 17 October 2018. This study uses the descriptive analysis method using parameter such as Outgoing Longwave Radiation (OLR) and Phase MJO diagram from Bureau of Meteorology (BOM), Sea Surface Temperature (SST) and vertical velocity data from the National Oceanic and Atmospheric Administration (NOAA) and also raw data of HCAI Himawari-8 satellite to monitor cloud formation on Sumatra and Java island and Global Precipitation Measurement (GPM) data obtained from the Meteorology, Climatology and Geophysics Agency (BMKG) to determine its rainfall distribution on $14-17$ October 2018. The active MJO in phase 3 causing an increase in convective activity on the Sumatra. The SST value of $29.5^{\circ}-30^{\circ}$ Celcius supports the occurrence of sufficient evaporation to produce convective clouds with a vertical velocity of less than - $0.12 \mathrm{~Pa} / \mathrm{s}$ (strong updraft) so as to form Cumulonimbus clouds which cause heavy rain intensity which can cause floods. However, in Java Island the influence of MJO was less significant due to the influence of relatively lower sea surface temperatures in the south of Java island so that it is not strong enough to form convective clouds that produce heavy rain.
\end{abstract}

Keywords: $M J O$, rainfall, convective

\begin{abstract}
Abstrak: Madden Julian Oscillation (MJO) merupakan gelombang di kawasan tropis yang menjalar dari Barat (Samudera Hindia) ke timur (Samudera Pasifik) dengan periode 30 - 60 hari. Banyak penelitian menjelaskan bahwa pada saat MJO aktif pada fase 2, 3 dan 4 berpengaruh terhadap giatnya aktivitas konvektif di Benua Maritim Indonesia. Penelitian ini bertujuan untuk mengetahui pengaruh MJO di fase 3 terhadap intensitas curah hujan secara temporal di wilayah Pulau Sumatra dan Pulau Jawa pada 14 - 17 Oktober 2018. Penelitian ini menggunakan metode analisis deskriptif dengan parameter antara lain : Outgoing Longwave Radiation (OLR) dan diagram fase MJO yang diambil dari Bureau of Meteorology (BOM), Sea Surface Temperature (SST) dan kecepatan vertikal yang diambil dari National Oceanic and Atmospheric Administration (NOAA) serta raw data HCAI satelit Himawari-8 untuk memonitoring pembentukan awan di Pulau Sumatera dan Jawa dan data Global Precipitation Measurement (GPM) yang didapatkan dari Badan Meteorologi, Klimatologi dan Geofisika (BMKG) untuk mengetahui distribusi curah hujannya pada 14 - 17 Oktober 2018. Aktifnya MJO pada fase 3 menyebabkan peningkatan aktivitas konvektif di Pulau Sumatera. Nilai SST sebesar $29.5^{0}-30^{\circ}$ Celcius mendukung terjadinya penguapan yang cukup untuk menghasilkan awan konvektif dengan kecepatan vertikal kurang dari $-0.12 \mathrm{~Pa} / \mathrm{s}$ (updraft kuat) sehingga membentuk awan Cumulonimbus yang menyebabkan intensitas hujan lebat yang mampu menimbulkan bencana banjir. Sedangkan di Pulau Jawa pengaruh MJO kurang signifikan akibat pengaruh suhu permukaan laut di
\end{abstract}


selatan Jawa yang relatif lebih rendah sehingga tidak cukup kuat untuk membentuk awan konvektif yang menghasilkan hujan lebat.

Kata kunci: MJO, curah hujan, konvektif.

\section{PENDAhULUAN}

Wilayah Indonesia yang berada di kawasan tropis menyebabkan Indonesia berpotensi menghasilkan banyak hujan. ${ }^{1}$ Menurut Tjasyono dan Harijono, 2006, dari aspek meteorologis, Indonesia merupakan Benua Maritim yang mempunyai kompleksitas dalam fenomena cuaca dan iklim. ${ }^{2}$ Salah satu penyebab kompleksitas tersebut antara lain adanya sirkulasi di wilayah ekuator yang berperan dalam osilasi antar musim dan terjadi dalam skala periode 30 hingga 60 harian yaitu Madden Jullian Oscilation (MJO). ${ }^{3}$ Dalam penelitiannya oleh Roland Madden dan Paul Julian (1972) dinyatakan bahwa osilasi ini memiliki periode 40 hingga 50 harian dengan cakupan wilayah $10^{\circ} \mathrm{LU}$ hingga $10^{\circ} \mathrm{LS}$. Sehingga, jika ditinjau dari letak geografis Indonesia, osilasi MJO memberikan pengaruh yang signifikan terhadap cuaca di wilayah tropis. $^{4}$ MJO menunjukan struktur vertikal yang kuat dengan konvergensi di lapisan bawah ketika anomali konvektivitas sangat kuat. Adanya gradien tekanan membuat osilasi ini dapat terpropagasi dari barat ke timur. ${ }^{5}$ Pada umumnya, MJO bergerak di sepanjang Samudera Hindia hingga Samudera Pasifik sehingga, memengaruhi cuaca tropis yang signifikan khususnya di Samudera Hindia, Benua Maritim Indonesia (BMI), dan Samudera Pasifik bagian Barat. ${ }^{1}$ Osilasi ini bermula dari pembentukan anomali tekanan rendah di permukaan di wilayah Samudera Hindia yang diikuti oleh peningkatan kelembapan pada lapisan batas, peningkatan konvektivitas, penghangatan troposfer dan peningkatan ketinggian troposfer. Berdasarkan diagram hovmoller, MJO pada fase 3 berada di sepanjang Samudera Hindia bagian Timur. Oleh karena itu, penelitian ini di fokuskan pada pengaruh MJO fase 3 terhadap curah hujan secara temporal dan spasial untuk wilayah Pulau Sumatera dan Pulau Jawa.

\section{METODE PENELITIAN}

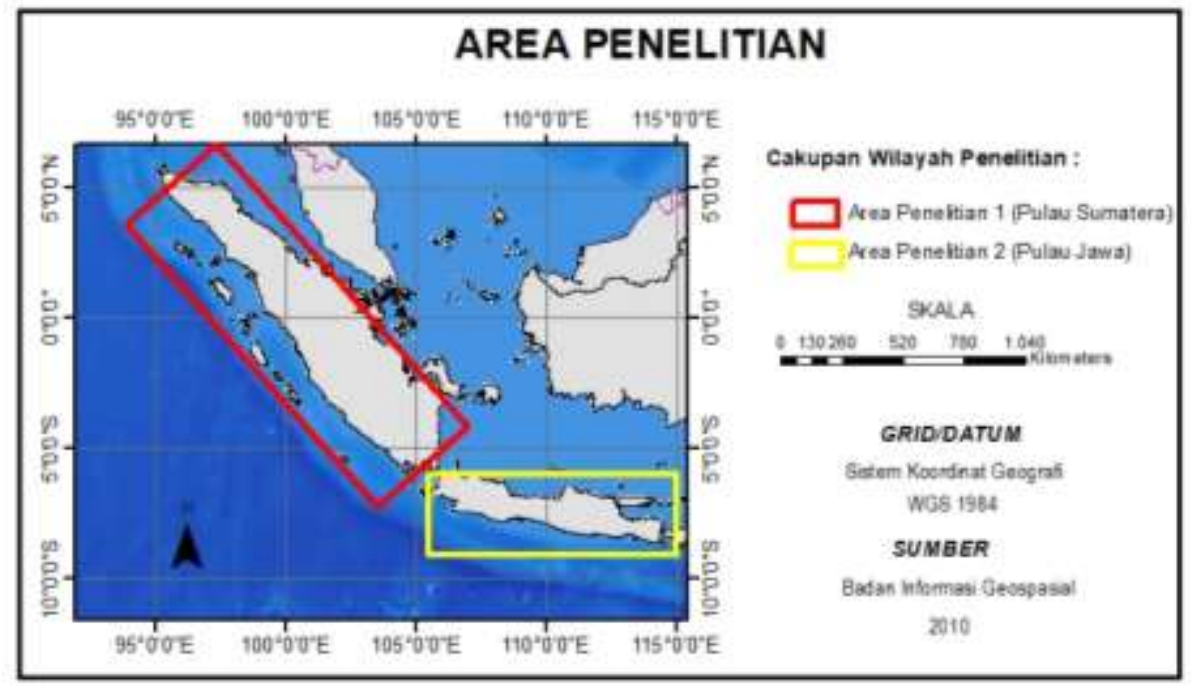

Gambar 1. Area penelitian di Pulau Sumatera dan Jawa

Data yang digunakan dalam penelitian ini menggunakan diagram fase $\mathrm{MJO}$, data OLR yang di unduh dari Bureau of Meteorology (BOM), raw data reanalisis kecepatan vertikal, SST dengan resolusi spasial $2.5^{\circ}$ x $2.5^{\circ}$ yang di unduh dari National Oceanic and Atmospheric Administration (NOAA) serta raw data High-resolution Cloud Analysis Information (HCAI) 
satelit Himawari-8 dengan resolusi spasial $0.02^{\circ}$ x $0.02^{0}$ dan raw data GPM dengan resolusi spasial $0.1^{0}$ x $0.1^{0}$ dari Badan Meteorologi Klimatologi dan Geofisika (BMKG). Periode data yang digunakan yaitu 14 - 17 Oktober 2018 dengan area penelitian 1 yaitu Pulau Sumatera dan area penelitian 2 yaitu Pulau Jawa (Gambar 1).

Penelitian ini menggunakan metode analisis diskriptif di mana diagram hovmoller digunakan untuk mengidentifikasi pergerakan fase MJO dan diagram OLR untuk mengindikasikan banyaknya tutupan awan. Sedangkan SST untuk mengetahui kondisi suhu muka laut, data kecepatan vertikal digunakan untuk mengetahui pergerakan massa udara ke atmosfer dan GPM untuk mengetahui jumlah curah hujan di area penelitian. Ketiga data tersebut diolah menggunakan software Grid Analysis and Display System (GrADS) dan ditampilkan dalam bentuk diagram. Untuk mengetahui awan yang terbentuk digunakan raw data HCAI dari satelit Himawari-8 yang diolah menggunakan aplikasi GMSLPC.exe. dengan output .jpeg. Selanjutnya, mengidentifikasi korelasi antara MJO fase 3 dan curah hujan di wilayah penelitian melalui parameter-parameter tersebut.

\section{HASIL DAN PEMBAHASAN}

\subsection{Identifikasi Pergerakan MJO}

Berdasarkan diagram hovmoller (Gambar.2) ditunjukan bahwa pada tanggal $14-17$ Oktober 2018 (garis berwarna biru), MJO berada di wilayah Samudera Hindia bagian Timur dengan sifat yang semakin lemah. Pada 14 - 16 Oktober 2018, pergerakan MJO dikategorikan kuat. Sedangkan pada 17 Oktober 2018, MJO di Samudera Hindia bersifat lemah (di dalam lingkaran).

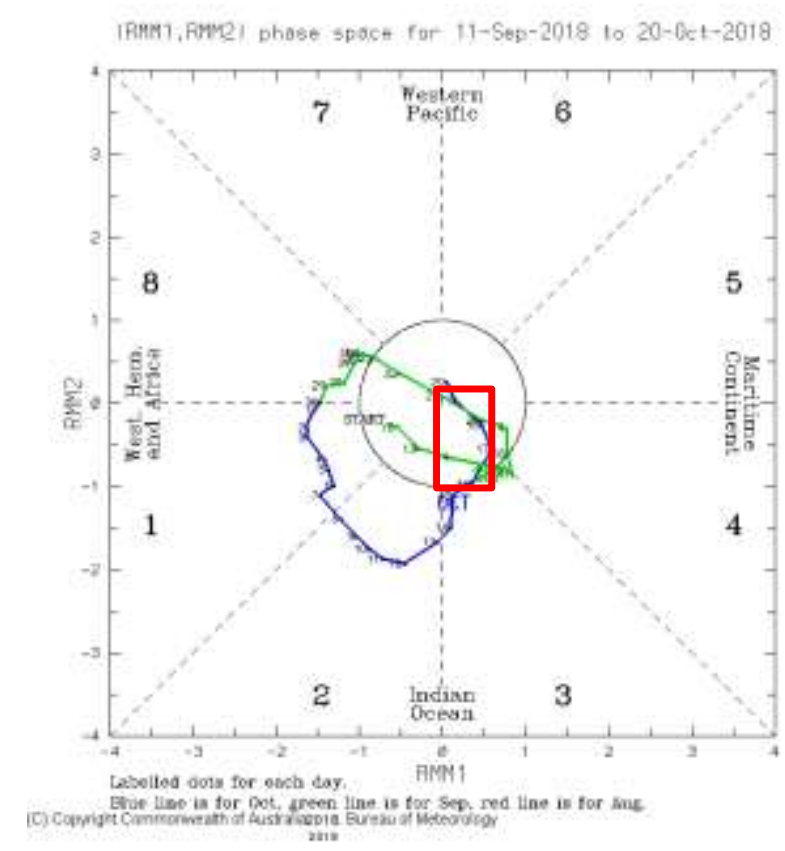

Gambar 2. Diagram Fase MJO bulan Oktober 2018 (kotak merah) (sumber : http://bom.gov.au) 


\subsection{Identifikasi Outgoing Long Radiation (OLR)}

${ }^{6}$ Menurut Supra, et al, 2011 dalam Prayuda, 2015, OLR merupakan sebuah parameter penting untuk mengetahui seberapa kuat konveksi di atmosfer. OLR mengindikasikan jumlah tutupan awan yang ada. Jika OLR rendah maka dapat diindikasikan bahwa banyak terbentuk awan, dikarenakan gelombang panjang yang keluar tertahan oleh awan, dan juga sebaliknya. Pada Gambar 3 menunjukan bahwa pada area penelitian 1 (Pulau Sumatera) memiliki nilai OLR sebesar -10 Watt $/ \mathrm{m}^{2}$ hingga $-50 \mathrm{Watt} / \mathrm{m}^{2}$. Nilai tersebut terbilang cukup rendah sehingga mengindikasikan bahwa di Pulau Sumatera pada umumnya banyak terbentuk awan-awan konvektif pada 14 - 17 Oktober 2018. Sedangkan pada area penelitian 2 (Pulau Jawa) memiliki nilai OLR sebesar $10 \mathrm{Watt} / \mathrm{m}^{2}$ hingga $30 \mathrm{Watt} / \mathrm{m}^{2}$ sehingga mengindikasikan bahwa tutupan awan yang menahan gelombang radiasi tersebut sedikit.

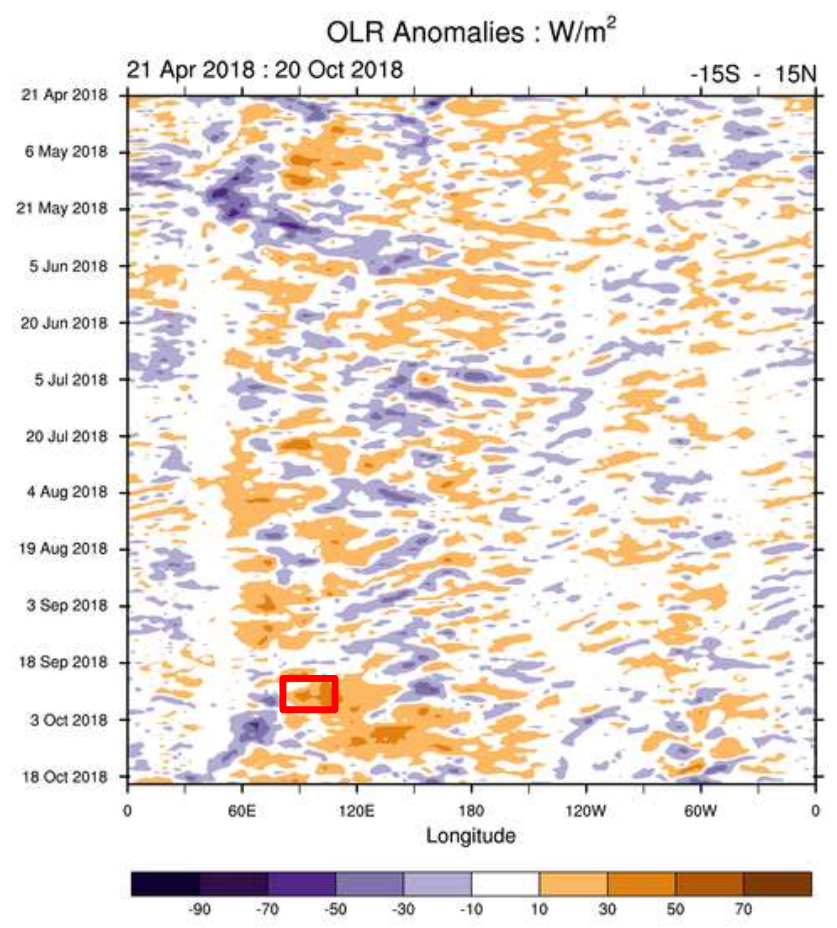

(C) Copyright Commonweatth of Australia 2018. Bureau of Meteorology

Gambar 3. Diagram Anomali OLR di area penelitian 14 - 17 Oktober 2018 (kotak merah)

(sumber : http://www.bom.gov.au)

\subsection{Identifikasi Gerak Udara Vertikal}

${ }^{7}$ Pergerakan massa udara dapat diketahui dengan mengetahui nilai parameter kecepatan vertikal. Pada Gambar 4 ditunjukan adanya nilai kecepatan vertikal dengan satuan $\mathrm{Pa} / \mathrm{s}$ pada 14 - 17 Oktober 2018 di wilayah Pulau Sumatera dan Jawa. Pada 14 Oktober 2018, nilai kecepatan vertikal di area penelitian 1 mencapai $-0.06 \mathrm{~Pa} / \mathrm{s}$ hingga $-0.15 \mathrm{~Pa} / \mathrm{s}$ mengindikasikan bahwa updraft yang terbentuk di Pulau Sumatera cukup kuat. Sedangkan di area penelitian 2, nilai kecepatan vertikal yang ditunjukan mencapai $-0.09 \mathrm{~Pa} / \mathrm{s}$ hingga $>0.03$ $\mathrm{Pa} / \mathrm{s}$. Hal tersebut mengindikasikan bahwa di Pulau Jawa terdapat daerah dengan updraft yang cukup kuat dan downdraft di mana pada Pulau Jawa bagian Barat $\left(6^{0}-7^{0}\right.$ LS dan $105^{\circ}-107^{0}$ 
BT) nilai kecepatan vertikal mencapai $-0.09 \mathrm{~Pa} / \mathrm{s}$ hingga $-0.03 \mathrm{~Pa} / \mathrm{s}$ yang mengindikasian area dengan updraft yang kuat. Sedangkan di Pulau Jawa bagian Tengah dan Timur, nilai kecepatan vertikal cenderung semakin positif yang menandakan bahwa area tersebut berpotensi terjadinya downdraft. Pada 15 Oktober 2018, nilai kecepatan vertikal yang ditunjukan di area penelitian 1 semakin rendah hingga mencapai $-0.18 \mathrm{~Pa} / \mathrm{s}$ terpusat di sekitar wilayah Padang dan cenderung melemah ke selatan Pulau Sumatera. Sedangkan nilai kecepatan vertikal di sebagian besar area penelitian 2 mencapai $0.03 \mathrm{~Pa} / \mathrm{s}$ yang mengindikasikan bahwa berpotensi terjadi downdraft. Pada 16 Oktober 2018, nilai kecepatan vertikal di area penelitian 1 cenderung sama hingga mencapai $-0.18 \mathrm{~Pa} / \mathrm{s}$ namun, semakin meluas ke timur sehingga potensi updraft dari area terpusat menuju timur sama kuatnya sehingga adanya updraft yang kuat berpotensi membentuk awan-awan konvektif. Sedangkan di area penelitian 2, di Jawa bagian Barat dan Jawa bagian Utara menunjukan updraft yang cukup kuat $(-0.03 \mathrm{~Pa} / \mathrm{s}$ hingga $0 \mathrm{~Pa} / \mathrm{s})$ sehingga berpotensi terbentuknya awan dan di Jawa bagian Selatan, updraft masih relatif lemah ditunjukan dengan nilai kecepatan vertikal masih direntang $0 \mathrm{~Pa} / \mathrm{s}-0,03 \mathrm{~Pa} / \mathrm{s}$ sehingga masih sulit terbentuk awan. Pada 17 Oktober 2018, updraft di area penelitian 1 semakin kuat ditunjukan dengan semakin rendah nilai kecepatan vertikal yang mencapai hingga kurang dari $-0.18 \mathrm{~Pa} / \mathrm{s}$. Penguatan updraft tersebut, terjadi di area terpusat yang semakin meluas seperti pada Gambar 4 (kanan bawah). Sedangkan, di area penelitian 2, kondisi masih cenderung sama di mana di Jawa bagian Selatan dan Jawa bagian Tengah (Semarang dan sekitarnya), serta Jawa bagian Barat (Bandung) potensi updraft masih relatif lemah dan di Jawa bagian Barat menuju Utara serta Jawa bagian Timur menuju Utara, potensi updraft cukup kuat untuk membentuk awan yang ditunjukan dengan nilai kecepatan vertikal mencapai $-0.03 \mathrm{~Pa} / \mathrm{s}$.
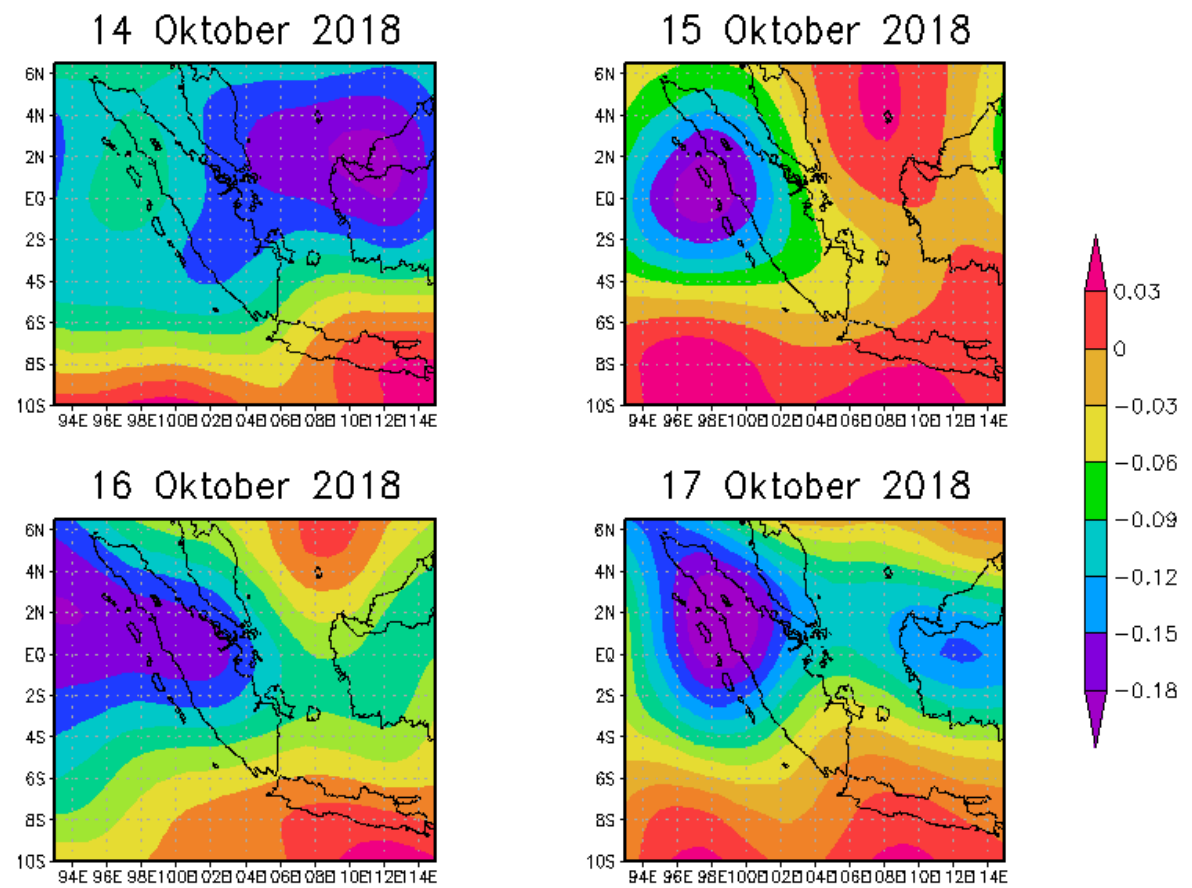

Gambar 4. Nilai Kecepatan Vertikal (Pa/s) jam 00UTC di Area Penelitian pada 14 Oktober 2018 (kiri atas), 15 Oktober 2018 (kanan atas), 16 Oktober 2018 (kiri bawah) dan 17 Oktober 2018 (kanan bawah)

\subsection{Distribusi Pertumbuhan Awan}


Memonitoring pertumbuhan awan dapat dilakukan dengan mengolah raw data HCAI satelit Himawari-8 untuk mengetahui jenis awan yang terbentuk di suatu wilayah tertentu. Berdasarkan Gambar 5, ditampilkan gambar pertumbuhan jenis-jenis awan yang terbentuk di area penelitian pada $14-17$ Oktober 2018 jam 12 UTC. Diketahui bahwa di area penelitian 1 terdapat pembentukan awan cumulonimbus yang ditandai dengan warna merah di bagian Selatan Sumetara dan beberapa awan awan menengah ditandai dengan warna kuning, sedangkan di Sumatera bagian Tengah menuju Utara terdeteksi sebagai dense di mana terdapat awan yang tumbuh tinggi namun tidak terkategorikan sebagai awan cumulonimbus. Di area penelitian 2, terbentuk sedikit awan awan menengah dan dense di area Pulau Jawa bagian Barat. Pada 15 Oktober 2018, di area penelitian 1 terdeteksi beberapa awan cumulonimbus di wilayah Sumatra bagian Utara terutama daerah terfokus dan beberapa awan awan menengah serta dense. Sedangkan di area penelitian 2, terbentuk awan awan menengah dan dense di beberapa titik namun, cenderung clear (tidak terdapat awan) di Jawa bagian Timur. Pada 16 Oktober 2018, di area penelitian 1 terbentuk awan cumulunimbus dengan jangkauan area yang relatif luas, dense dan awan awan menengah dibeberapa titik. Sedangkan, di area penelitian 2 terpantau awan cumulunimbus dengan jangkauan yang sempit, dense dan awan menengah di Pulau Jawa bagian Barat, namun cenderung clear di daerah Jawa bagian Tengah dan Timur. Pada 17 Oktober 2018, terpantau adanya awan cumulonimbus di beberapa titik di area penelitian 1 dengan jangkauan wilayah yang relatif sempit, dense dan awan awan menengah dibeberapa titik di Pulau Sumatra. Sedangkan, di area penelitian 2, terpantau awan awan menengah di beberapa titik namun secara keseluruhan cenderung cerah (tidak ada awan).
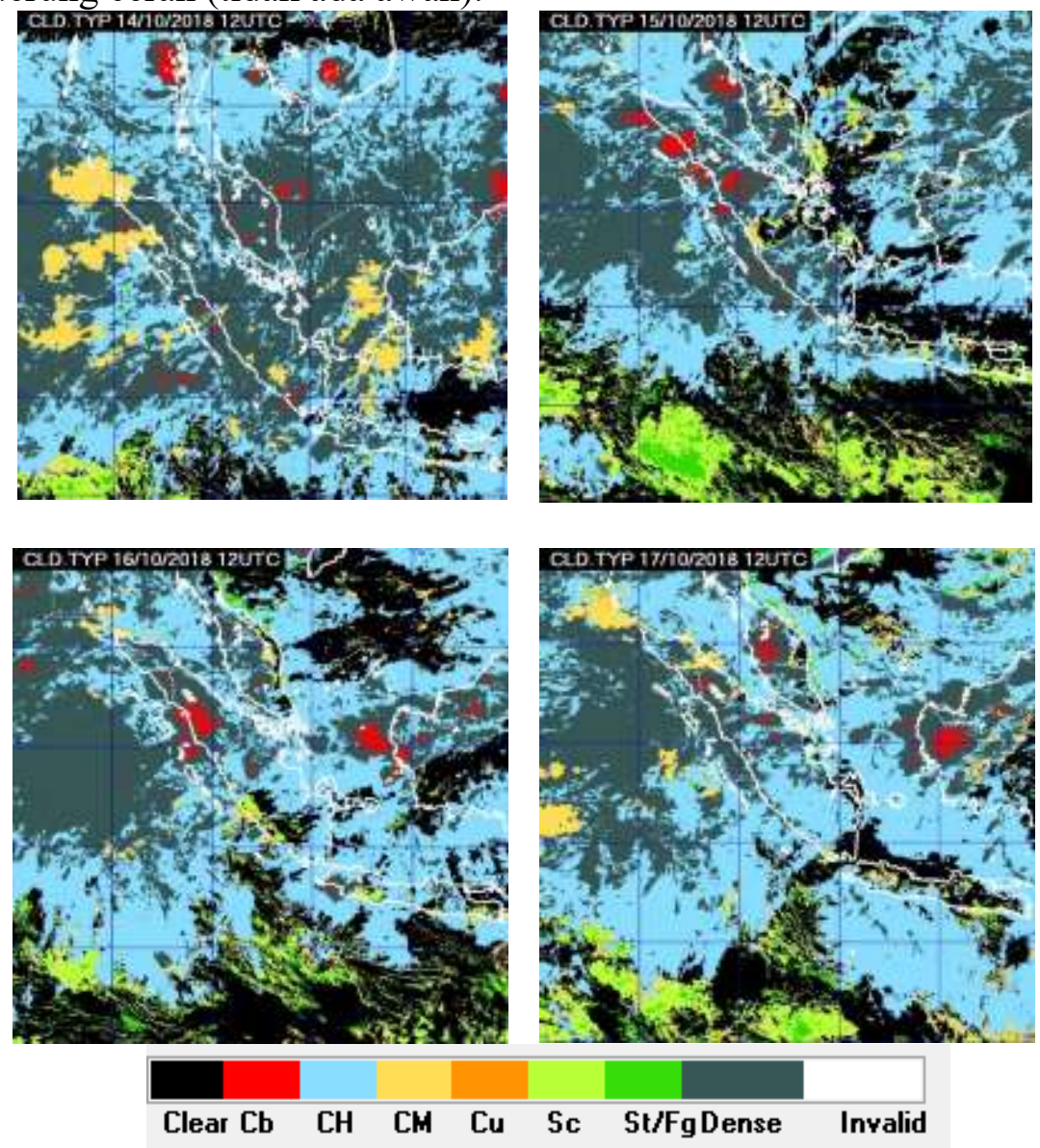

Gambar 5.

Pertumbuhan Awan jam 12UTC di Area Penelitian pada 14 Oktober 2018 (kiri atas), 15

Oktober 2018

(kanan atas), 16

Oktober 2018(kiri bawah) dan 17

Oktober 2018

(kanan bawah) 


\subsection{Distribusi Sea Surface Temperature (SST)}

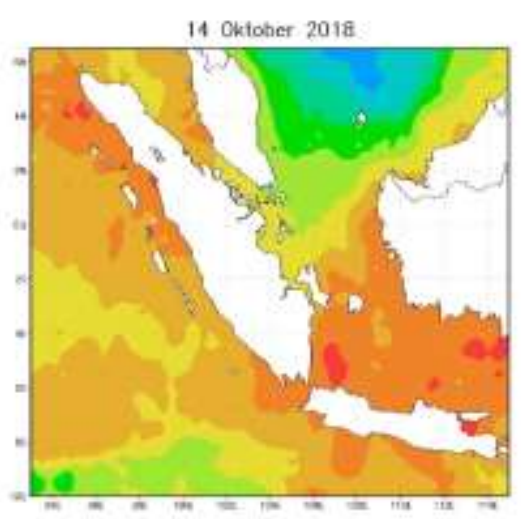

16 Oktuber 2018

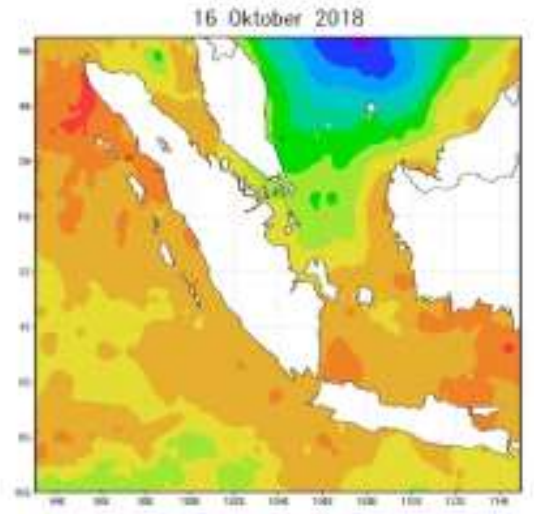

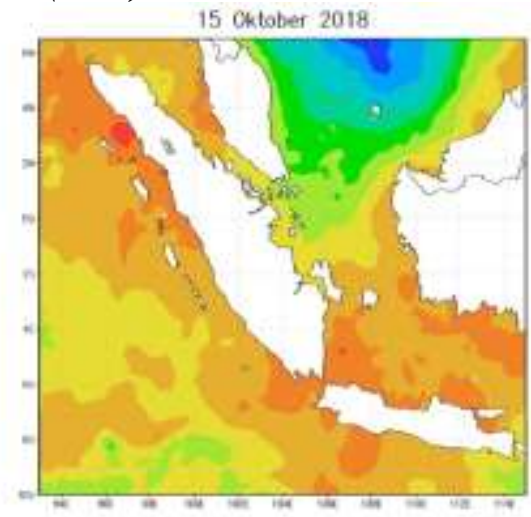

17 Oktober 2018

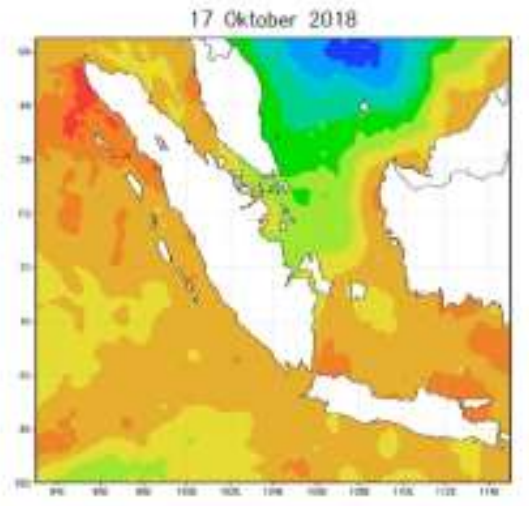

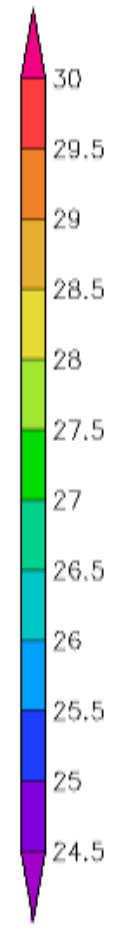

Gambar 6. Distribusi Sea Surface Temperature Jam 00 UTC di Area Penelitian pada 14 Oktober 2018 (kiri atas), 15 Oktober 2018 (kanan atas), 16 Oktober 2018(kiri bawah) dan 17 Oktober 2018 (kanan bawah)

Berdasarkan Gambar 6 ditunjukan nilai suhu permukaan laut di area penelitian. Pada 14 Oktober 2018 suhu di sebelah barat area penelitian 1 mencapai $28.5^{\circ}-30^{\circ}$ Celcius, menunjukan bahwa suhu laut di sekitar wilayah barat area penelitian relatif hangat dan memicu untuk terjadinya penguapan yang menimbulkan terbentuknya awan - awan konvektif. Sedangkan, di selatan area penelitian 2, suhu permukaan laut yang ditunjukan relatif lebih rendah jika dibandingkan dengan area penelitian 1 di mana suhu permukaan lautnya $28.5^{\circ}$ $29^{0}$ Celcius. Pada 15 Oktober 2018 suhu permukaan laut di sebelah barat area penelitian 1 mencapai 28.5 - 30 Celcius dimana rentang suhu $29.5^{\circ}-30^{\circ}$ Celcius lebih banyak terdapat di area utara penelitian, sehingga potensi penguapan di area utara penelitian lebih besar jika dibanding daerah lainnya. Akibatnya, banyak awan-awan konvektif yang terbentuk di area utara penelitian (Sumatera bagian Utara). Sedangkan, di selatan area penelitian 2, suhu permukaan laut mencapai $28.5^{\circ}-29^{0}$ Celcius di selatan Jawa bagian Tengah, $28^{0}-28.5^{0}$ Celcius di Jawa bagian Timur dan $29^{\circ}-29.5^{\circ}$ Celcius di selatan Jawa bagian Barat. Pada 16 Oktober 2018 suhu muka laut di sebelah barat wilayah penelitian 1 mencapai $28.5^{\circ}-29^{0}$ Celcius di sebelah barat Sumatera bagian Tengah dan Selatan. Namun, semakin meningkat di bagian barat Sumatera bagian Utara hingga mencapai $30^{\circ}$ Celcius. Sedangkan, di selatan area penelitian 2, suhu muka lautnya mencapai $28^{\circ}-29^{\circ}$ Celcius, relatif lebih rendah dibanding area penelitian 1. Pada 17 Oktober 2018 kondisi suhu permukaan laut di sebelah barat area penelitian 1 relatif sama dengan hari sebelumnya di mana suhunya mencapai $30^{\circ}$ Celcius (di 
sebelah barat bagian Sumatera bagian Utara) dan di selatan area penelitian 2 suhu permukaan lautnya mencapai $28^{0}-29^{0}$ Celcius dengan dominasi suhu permukaan laut pada rentang $28.5^{\circ}$ $-29^{0}$ Celcius. Semakin tinggi suhu permukaan laut, semakin besar potensi untuk memicu terjadinya penguapan yang menimbulkan terbentuknya awan-awan konvektif.

\subsection{Identifikasi Curah Hujan}

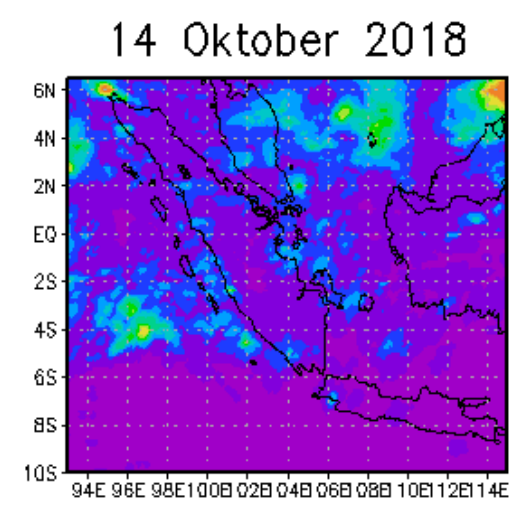

16 Oktober 2018

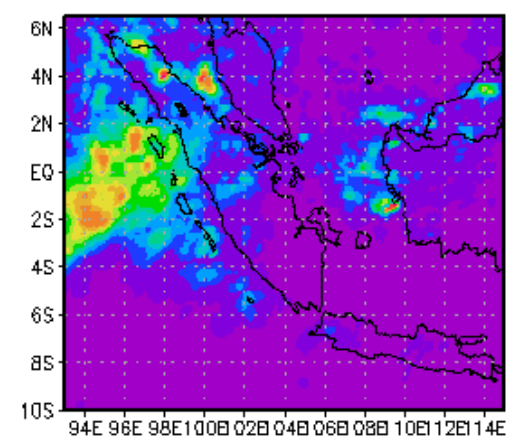

15 Oktober 2018

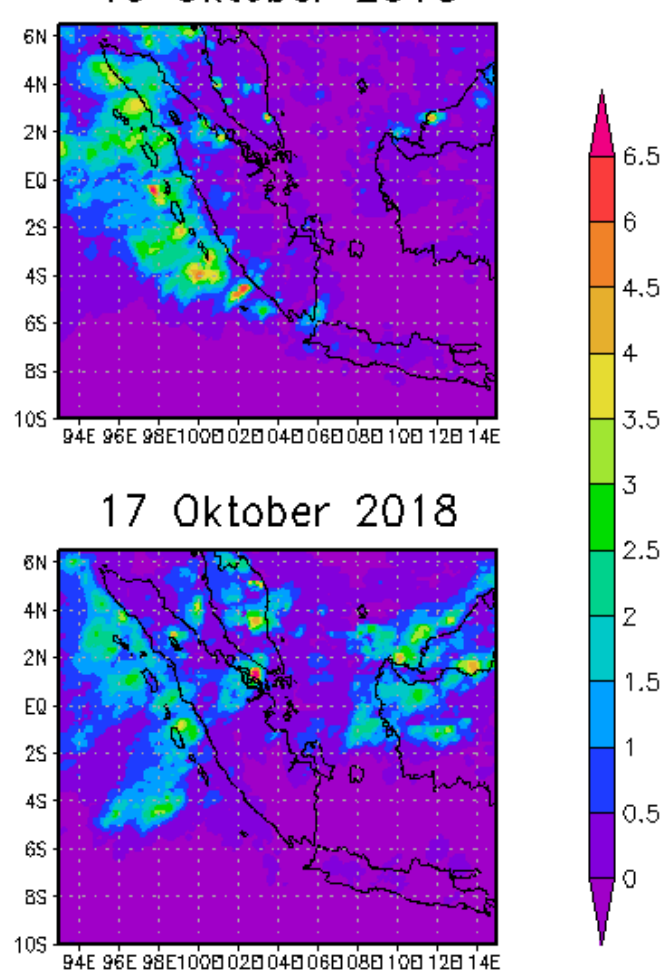

Gambar 7. Rata - rata jumlah curah hujan di Area Penelitian pada 14 Oktober 2018 (kiri atas), 15 Oktober 2018 (kanan atas), 16 Oktober 2018(kiri bawah) dan 17 Oktober 2018

(kanan bawah)

Pada 14 Oktober 2018 di Pulau Sumatera sebagian besar terjadi hujan dengan intensitas ringan dengan rata-rata hujan harian $1-1.5 \mathrm{~mm} /$ hari sedangkan Pulau Jawa hujan hanya terjadi di Jawa bagian Barat dan Tengah dengan cakupan wilayah yang sempit, rata-rata hujan hariannya mencapai $0.5-1 \mathrm{~mm} /$ hari. Pada 15 Oktober 2018 terjadi peningkatan intensitas hujan dengan rata-rata hujan harian mencapai $3.5 \mathrm{~mm} / \mathrm{hari}$ di Sumatera bagian Utara. Sedangkan di Pulau Jawa rata-rata hujan hariannya menunjukan nilai yang sama namun, cakupan wilayahnya lebih luas. Pada 16 Oktober 2018 intensitas hujan di Sumatera bagian Tengah hingga Utara meningkat mencapai $1.5-6 \mathrm{~mm} /$ hari sedangkan di Sumatera bagian Selatan cenderung ringan bahkan tidak terdapat hujan. Di Pulau Jawa intensitas hujannya sama dengan jangkauan wilayah yang lebih sempit dibanding hari sebelumnya. Pada 17 Oktober 2018 hujan masih didominasi di Sumatera bagian Utara dengan rata-rata hujan harian mencapai $4.5 \mathrm{~mm} /$ hari sedangkan di Pulau Jawa hujan dengan intensitas ringan terjadi di beberapa titik dengan jangkauan wilayah yang sempit dan cenderung didominasi tidak ada hujan. 


\section{KESIMPULAN}

Berdasarkan identifikasi menggunakan parameter OLR, SST dan kecepatan vertikal menunjukan bahwa pada saat MJO fase 3 aktif di Samudera Hindia bagian Timur berpotensi memengaruhi pembentukan awan-awan konvektif yang menghasilkan hujan di Pulau Sumatera dengan intensitas sedang - lebat. OLR bernilai $-50 \mathrm{Watt} / \mathrm{m}^{2}$ menunjukan banyaknya tutupan awan yang terbentuk. SST bernilai $29.5^{\circ}-30^{0}$ Celcius memicu terjadinya penguapan yang cukup untuk menghasilkan awan konvektif serta kecepatan vertikal dengan nilai kurang dari $-0.12 \mathrm{~Pa} / \mathrm{s}$ menunjukan updraft yang kuat untuk membentuk awan cumulunimbus yang terpantau dari citra satelit Himawari-8. Kejadian hujan dengan intensitas sedang hingga lebat terjadi di Sumatera bagian Utara sedangkan di Pulau Jawa hujan cenderung ringan bahkan didominasi tidak terjadi hujan (cuaca cerah) akibat suhu muka laut di selatan Jawa yang relatif lebih rendah sehingga penguapan masih tidak cukup untuk membentuk awan konvektif yang menghasilkan hujan dengan intensitas lebat.

\section{SARAN}

Perlu tinjauan faktor lokal untuk lebih mengetahui pengaruh MJO fase 3 terhadap curah hujan secara spasial serta diperlukan data pembanding observasi curah hujan dipermukaan.

\section{DAFTAR PUSTAKA}

Tjasyono, B.H.K. dan Harijono, Sri Woro B.. (2006). Meteorologi Indonesia 2: Awan dan Hujan Monsun. Jakarta: Badan Meteorologi Klimatologi dan Geofisika.

Ahrens, C.D. dan Henson. R. (2016). Meteorology Today An Introduction to Weather, Climate, and the Environment. USA: Cengage Learning

Madden, J. A dan Julian, P. R. 1972. Description of Global-Scale Circulation Cells in the Tropics with a 40-50 Day Period. Journal of The Atmospheric Volume 29, 11091123. USA: American Meteorological Society

Sperber K.R. (2003). Propagation and the Vertical Structure of the Madden-Julian Oscillation. Monthly Weather Review Volume 131, 3018-3037. USA: American Meteorological Society

Arbain, A.A. dan Renggono, Findy. (2017). Pengaruh Madden - Julian Oscillation terhadap Distribusi Temporal dan Propagasi Hujan di Wilayah Jakarta dan Sekitarnya Selama Periode IOP2016 Berdasarkan Pengamatan Radar Cuaca. Jurnal Sains \& Teknologi Modifikasi Cuaca. Volume 18, No.2. pp. 49 - 55.

Prayuda, .S.S. dan Alfuadi, Nanda. (2015). Pengaruh Convective Avaliable Potential Energy (CAPE) Dan Outgoing Longwave Radiation (OLR) terhadap Curah Hujan di Cengkareng. Prosiding Seminar Nasional Fisika dan Aplikasinya. Universitas Padjadjaran. hal. $47-55$.

Saragih R.M et al. 2018. Atmospheric study of the impact of Borneo vortex and MaddenJulian oscillation over Western Indonesian maritime area. Journal of Physics:Conferensi Series, 997, 012004. http://doi :10.1088/17426596/997/1/012004

http://www.bom.go.au (diakses pada 16 Oktober 2018) 